\title{
Ortaokul Öğrencilerinin Okuma Kaygıları ve Akademik Özyeterlik İnançlarının Çeşitli Değişkenler Açısından İncelenmesi
}

\section{Investigation of Secondary School Students' Reading Anxiety and Academic Self-Efficacy Beliefs in Terms of Various Variables}

\author{
Aysel ARSLAN \\ Atatürk Üniversitesi, Eğitim Bilimleri, Ĕ̆itim Programlart ve Öğretim, Erzurum \\ arslanaysel.58@gmail.com
}

Atıf: Arslan, A. (2017). Ortaokul Öğrencilerinin Okuma Kaygıları ve Akademik Özyeterlik İnançlarının Çeşitli Değişkenler Açısından İncelenmesi. E-Kafkas Ĕgitim Araşstırmaları Dergisi, 4(3), 30-44.

\begin{abstract}
Özet
$\mathrm{Bu}$ araştırmanın amacı ortaokul öğrencilerinin okuma kaygıları ve akademik özyeterliklerinin cinsiyet, sınıf, anne ve baba eğitim durumu değişkenlerine göre incelenmesi ve okuma kaygıları ile akademik özyeterlikleri arasındaki korelasyonun belirlenmesidir. Araştırma yöntemi olarak ilişkisel araştırma modeli içinde bulunan tesadüfi olmayan örnekleme yöntemi kullanılmıştır. Araştırmanın örneklemini 2016-2017 eğitim-öğretim yılı bahar döneminde Sivas il merkezinde bulunan 11 farklı ortaokulda eğitim görmekte olan 241 kız, 255 erkek olmak üzere toplamda 496 öğrenci oluşturmaktadır. Öğrencilerin okumaya yönelik kaygılarını belirlemek amacıyla Çeliktürk ve Yamaç (2015) tarafindan geliştirilen "Okuma Kaygısı Ölçeği" kullanılmıştır. Ölçeğin güvenirliği .92 bu çalışmada ise .96 olarak bulunmuştur. Öğrencilerin akademik özyeterliklerini belirlemek amacıyla Muris (2001) tarafindan geliştirilen Türkçeye uyarlaması ise Telef ve Karaca (2012) tarafindan yapılan “Çocuklar İçin Özyeterlik Ölçeği” ”nin alt ölçeği olan “Akademik Özyeterlik Ölçeğì" kullanılmıştır. Ölçeğin güvenirliği .86 bu çalışmada ise .82 olarak bulunmuştur. Araştırmaya ilişkin veriler Kolmogorov-Smirnov (K-S), Aritmetik Ortalama, Standart Sapma, Bağımsız T Testi, Anova, LSD, Spearman Brown Korelasyon Katsayısı kullanılarak analiz edilmiştir. Yapılan analizler sonucunda elde edilen bulgular incelendiğinde; öğrencilerin okuma kaygılarının sınıf ve baba eğitim durumu değişkenleri; akademik özyeterliklerinin sınıf, anne ve baba eğitim durumu değişkenleri açısından farklılaştığı tespit edilmiştir. Öğrencilerin akademik özyeterlikleri ile okuma kaygı puanlarının korelasyon sonuçlarına göre aralarında negatif yönde orta düzeyde bir ilişkinin (-.34) olduğu görülmüştür.
\end{abstract}

Anahtar Kelimeler: Kayg1, Okuma Kaygısı, Özyeterlik, Öğrenci, Eğitim

\begin{abstract}
This study aims to determine whether there is a difference in the reading anxiety and academic self-efficacy beliefs of secondary school students in terms of gender, grade level, educational status of the mother and the father variables and the correlation between reading anxieties and academic self-efficacies of the students. In the study, non-random sampling method in relational method was used as the research method. The study was conducted on 496 students, 241 females and 255 males in 11 different secondary schools from Sivas province centre in 2016-2017 academic years during spring semester. The "Reading Anxiety Scale" developed Çeliktürk and Yamaç (2015) was used to determine the reading anxiety levels of students. The reliability of the scale is .92 and it was found as .96 in this study. The "Academic Self-Efficacy Scale" as the subscale of the "Self-Efficacy Scale for Students" adapted by Telef and Karaca (2012) developed by Muris (2001) was used in order to determine the academic self-efficacy of the students. The reliability of the scale is .86 and it was found as .82 in this study. In the data analysis, arithmetic average, percentage, T-test, Anova, LSD and correlation analysis techniques were used to analyse the data about the study. When the findings obtained were analysed, it was determined that the students' reading anxiety differed significantly according to class, father education status variables; the students' academic self-efficacy differed significantly according to class, mother education status and father education status variables. According to the correlation results of students' academic self-efficacy and reading anxiety total scores were found out to be moderate and in negative way $(-.34)$.
\end{abstract}

Keywords: Anxiety, Reading anxety, Self-efficacy, Student, Education

\section{GİRiș}

İnsanın dile ilişkin dört temel becerisi arasında yer alan konuşma ve yazma anlatma; okuma ve dinleme ise anlama becerileri olarak ifade edilmektedir. Birey bu beceriler aracılığıyla yeni bilgilere ulaşmaktadır. Günümüzdeki bireyin bilgi elde etmek için kullandığı iletişim araçları da daha çok görselliğe dayandığı için bireylerin gördüklerini ve izlediklerini anlama becerilerinin gelişmiş olması gerekmektedir (Özbay, 2009, s: 2). Okuma, bireyin hem akademik hayatında hem de günlük yaşamında oldukça önemli olan bir beceridir. Bu becerinin doğru ve etkili olarak kazandırılmasıyla doğru ve akıcı okuyan, okuduklarını anlamlandıran, okuduklarından öğrendiklerini veya okuduklarıyla ilgili düşüncelerini sözlü ve yazılı olarak aktarabilen bireyler yetiştirilebilmektedir (Çeliktürk \& Yamaç, 2015, s: 98). Bireyin anlama ve bilgi edinme yolları arasında oldukça önemli olan okuma (Özbay, 2009, s: 1) ile ilgili alan yazında pek çok farklı tanım bulunmaktadır. Okumak metni sözlü dile dönüştürülmesi ve metinden anlam kurulması olarak tanımlanmıştır (Binbaşığlu, 1973, s: 15; Coltheart, 2005; Göğüş, 1978, s: 60; Haris \& Sipay, 1990, s: 10). Özdemir (1990, s: 13) okumanın basılı sözcükleri kavrama ve yorumlamaya dayanan zihinsel bir etkinlik olduğunu söylerken; Akyol (2011), yazar ve okuyucu arasındaki 
etkileşimin aktif olarak gerçekleştirildiği dinamik bir anlam kurma süreci olduğunu söylemektedir. Tazebay (1993, s: 3) okumanın; bir metindeki harflerin, kelimelerin tanınarak anlamlarını kavrama sürecine yönelik olarak göz ve ses organlarının çeşitli hareketleri, zihnin anlam kurma çabasından oluşan karmaşık bir etkinlik olduğunu belirtmektedir. Özbay $(2009$, s: 2$)$ da benzer bir ifadeyle okumanın hem fiziksel hem de zihinsel öğelerin birlikte kullanıldığı karmaşık bir etkinlik olduğunu söylemektedir. Rozan (1982, s: 19) okumanın, bir sayfadaki işaretlerin belirli kurallar çerçevesinde seslendirilmesi olduğunu söylemektedir. Demirel (1999, s: 59) ise okumanın, bilişsel davranışlarla psikomotor becerilerin birlikte kullanılması sonucu yazılı işaretlerden anlam kurma olduğunu ifade etmektedir. Johnson (2008) okumanın anlam kurma sürecinde bir metnin kullanılması olduğunu söylemektedir. Şahin, (2011, s: 1) okumanın geniş anlamda bireyin duyu organlarıyla evrendeki tüm varlıkları tanıması ve anlamlandırması, dar anlamda ise yazılı işaret ve sembolleri çözümleme becerisi kazanması olduğunu belirtmektedir. Okuma bireyin yeni bilgiler edinmesi ve bildiklerini geliştirmesinin temel aracı olarak kabul edildiği için dört temel dil becerisi arasında özellikle önemli kabul edilmektedir (Grabe \& Stoller, 2002). Okumanın gerçek amacının, okunanların doğru ve hızlı olarak kavranması olduğu belirtilmektedir (Bamberger, 1990, s: 1)

Okuma; herhangi bir dile ait seslerin yazılı metindeki karşıllı̆ı olarak ifade edilen işaretlerle eşleştirilmesiyle oluşturulan kelime ve cümleler sayesinde anlamın çözümlenmesi, anlamlandırılması ve yorumlanması olarak tanımlanmaktadır. Birey anlamı çözümleme, oluşturma ve yorumlama süreçleri boyunca hem bilişsel hem de duyuşsal boyutta etkindir. Okuma faaliyeti sırasında bireyin hissettiği okuma kaygısı da bu sürecin duyuşsal boyutunda yer almaktadır (Altunkaya, 2017, s: 110; Alverman \& Guthrie, 1993). Tekindal (2009) bireyin okuma becerisinin seviyesi hakkında karar verilirken duyuşsal boyutta hissettiklerinin de dikkate alınması gerektiğini ifade etmektedir. Çünkü bireyin okuma sürecinde hissettiği kaygı okumayı anlamlandırma becerisini etkilemekte (Altunkaya \& Erdem, 2017, s: 60), öğrenmeye olumlu veya olumsuz bir etkide bulunabilmektedir (Williams, Vickers \& Rodriges, 2002). Elliott ve Smith (2010) kaygıyı, bireyin hissettiği huzursuzluk, endişe, kuruntu ve korkulardan oluşan duygusal durum olarak tanımlamıştır. Kaygı bir anlamda bireyin bir nesne veya duruma yönelik olarak psikolojik boyutta hissettiklerinin duyuşsal, bilişsel ve psikolojik olumsuz tepkiler şeklinde dışa vurumu olarak da ifade edilebilir (Çeliktürk \& Yamaç, 2015: 98). Eysenck, Derakshan, Santos ve Calvo (2007) kaygının bireyin tehdit hissettiği durumlarda oluşan caydırıcı ve motivasyonel bir durum olduğunu söylerken; Turgut, (1978, s: 158) bireyin gelmesinden korktuğu bir tehlikeden korkma durumu; Bandura (1977) ise bireyin olası zarar görebileceği olaylara ilişkin hissettiği endişe hali olduğunu ifade etmektedir. Zeidner (1998) kaygının bireyin endişelenmesi, konuyla alakasız şeyler düşünmesi vb. durumları içeren yönüyle bilişsel; gerginlik hissetmesi, farklı bedensel tepkiler göstermesi vb. durumları içeren yönüyle duyuşsal; yetersiz çalışma, erteleme, kaçınma vb. durumları içeren yönüyle de davranışsal olarak üç farklı kategoride değerlendirilmesi gerektiğini söylemektedir. İșeri ve Ünal (2012) kaygının geçici ve sürekli kaygı olarak iki farklı şekilde görüldügünnü belirtmektedir. Geçici kaygının daha çok karşılanamayan bir istek veya ihtiyacın ortaya çıkmasıyla oluştuğunu ve bireyin gereksinimleri karşıladığında ortadan kaybolduğunu; sürekli kaygının ise güvenliğin tehdit altında olduğu durumlarda ortaya çıktığını ve bireyi tehdit eden durumun uzun süreli olmasından kaynaklandığını söylemektedir. Andrade ve Williams (2009) ise kaygının kişisel, durum, iletişim, sınıf ortamı, test, dinleme, konuşma, okuma, yazma kaygısı vb. pek çok çeşidi olduğunu ifade etmektedir. Bu kaygılar arasında görülen okuma kaygısı bireyin okuma sürecinde duygusal olarak hayal kırıklığı, yetersizlik hissi, üzüntü, korku vb. şekillerde; fiziksel olarak terleme, kalp çarpıntısı, kızarma vb. şekillerde görülebilen bir tepki durumu olarak tanımlanmaktadır (Altunkaya, 2017, s: 110). Okumaya yönelik kaygı durumunda öncelikle ruhsal olarak ortaya çıkmakta sonrasında ise fiziksel belirtiler de görülebilmektedir (Altunkaya, 2015). Zbornik (2001) okuma kaygısının fiziksel ve bilişsel tepkiler içeren okuma etkinliğine yönelik olarak ortaya çıkan spesifik ve durumsal bir fobi olduğunu söylemektedir (Aktaran Jalongo \& Hirsh, 2010, s: 434).

Okuma kaygısı bireyin okumasının zorunlu olduğu okuma etkinliği, sınav vb. durumlarda ortaya çıkabildiği gibi okumasının zorunlu olmadığı durumlarda da ortaya çıkabilmektedir (Torgesen, 2000). Guimba ve Alico (2015) okuma kaygısının nedenlerinin temelde üç kategoriye ayrıldığını bunların: Yukarıdan aşağıya okuma, aşağıdan yukarı okuma ve sınıftaki okuma olduğunu belirtmektedir. Akyol (2007) okuma sürecinin okuma öncesi, sırası ve sonrası olmak üzere üç farklı aşamadan oluştuğunu belirtmektedir. Bireyin yaşadığı okuma kaygısını değerlendirirken bu üç aşama dikkate alınmalıdır. Okuma amacının belirlenememesi, okuma materyali hakkında bilgi eksikliğinin olması vb. durumlar okuma öncesine; uygun stratejilerin kullanılmaması, dikkat dağınıklı̆g vb. okuma sırasına (Tobias, 1986); yeni öğrenilen bilgilerle daha önceki bilgiler arasında bağlantı kurulamaması okuma sonrasına (Koizimu, 2002) ilişkin kaygı durumlarının yaşanmasına neden olmaktadır. Bireyin okuma sürecinde kaygı yaşamasının önüne geçmek için onu cesaretlendirecek, güdüleyecek ve yaşadığı kaygı durumunu azaltacak tedbirlerin alınması gerekmektedir (Altunkaya, 2015). Pekrun, Goetz, Frenzel, Barchfeld, ve Perry (2011) kaygı durumlarına ilişkin yapılan değerlendirmelerde duyuşsal, fizyolojik, psikolojik boyutların yanında motivasyonel boyutun da önemli olduğunu söylemektedir. Tüm bu boyutlar birbiri ile ilişkili olarak ilerlemekte ve bireyin psikolojisi üzerinde etkili olmaktadır (Pekrun, 2006; Pekrun, Goetz ve Perry, 2005). Bireyin motivasyonel süreçlerde başarılı olması, kendine yönelik güven duygusunun gelişmesi ve yeterlik algılarının yüksek olması da kaygı durumlarıyla baş etmesini kolaylaştırmaktadır. Melanlığlu (2014, s: 107) üstbilişsel 
stratejileri kullanmanın öğrencilerin okuma kaygılarını azaltmada önemli bir etken olduğunu belirtmektedir. Bu durumda özyeterliği yüksek olan bireylerin okuma kaygısıyla daha kolay baş edebileceği söylenebilir.

Özyeterlik kavramı ilk kez Bandura tarafından geliştirilen Sosyal Öğrenme Kuramının merkezinde yer alan temelinde bireyin kendine yönelik motivasyon algısının olduğu başlıca kavramlardan biridir (Akar, 2008, s: 186; Bandura, 1986, s: 391; Derman, 2007; Pajares, 2002). Kavramın temelinde bireyin kendi psikolojik süreçlerinin onun yeterlik beklentisini oluşturmasına ve geliştirmesine yardımcı olduğu yer almaktadır (Akar, 2008, s: 186; Bandura, 1986, s: 391). Bandura (1997) bireyin performansının istenilen seviyede olabilmesi için sahip olduğu becerileri etkin olarak ve kendine güvenerek kullanmasının önemli olduğunu ve bunun içinde özyeterlik inancının yüksek olması gerektiğini söylemektedir. Bireyler özyeterlik inançlarını, kendi yeteneklerini kullanarak istedikleri başarılar ve geleceğe dönük beklentilerini gerçekleştirmek için kullanmaktadırlar (Bandura, 1986, s: 391; Linnenbrink \& Pintrich, 2003; Senemoğlu, 2005). Özyeterlik kavramını Bandura (1997) bireyin belirli bir performansı gerçekleştirmesine ilişkin gerekli olan etkinlikleri organize etmesi ve başarılı bir şekilde sonuçlandırmasına yönelik kendine dönük yargısı olarak tanımlamakta, özyeterlik inancının bireyin ilgili konuda ne kadar bilgili ve yetkin olduğuyla ilgisinin olmadığını kendi yapabileceklerine ilişkin inancı olduğunu ifade etmektedir. Tschannen Moren ve Hoy (2001, s: 792) özyeterlik inancının, bireyin karşılaştığı yeni durumlara yönelik olarak ne derece başarılı olacağına ilişkin kendisine dönük beklentileri olduğunu söylemektedir. Hoy ve Woolfolk (1993) özyeterlik inancının bireyin kendi yeteneklerini karşılaştığ durumlara göre organize edebilmesi ve geliştirebilmesi; Açıkgöz (1996) ise bireyin karşılaştığı durumlar karşısında kendi performansına yönelik güven durumu olarak ifade etmiştir. Yapılan tanımlar dikkate alındığında özyeterliğin bir beceri değil oluşan şartlar karşısında bireyin sahip olduğu becerileri kullanarak "ne yapabilirim" sorusuna ilişkin verdiği yanıta yönelik duyduğu inanç olduğu görülmektedir (Acar, 2005; Bandura, 1997; Chapman \& Tunmer, 2003). Bir konuda özyeterlik inancı yüksek olan bireyin karşılaştığı problem durumlarıyla baş etmelerinin daha kolay olduğu ifade edilmektedir (Compeau \& Higgins, 1995; Karsten \& Roth, 1998).

Bireylerin karşılaştıkları olaylara ilişkin etkilenme durumları ve tepkileri, bir işin üstesinden gelebilmeleri için gereken güdülenmeleri, gerçekte sahip olduklarından daha çok kendilerine yönelik inançlarına bağlı bulunmaktadır. $\mathrm{Bu}$ inançlar, bireyin nasıl hissettiğini, düşündüğünü, motive durumlarını ve tepkilerini belirlemektedir (Üredi \& Üredi, 2006). Özyeterlik inançlarına ilişkin bilgiyi elde etmek için bireyler kendi yaşantıları, başkalarının yaşantıları, sözel olarak ikna etme biçimleri ve psikolojik kanıtları kullanmaktadırlar (Bandura \& Adams, 1977; Bandura, 1984, 1997, 2001; Özenoğlu Kiremit, 2006). Bireylerin bu bilgi kaynaklarından elde ettikleri bilgiler özyeterlik inancını doğrudan belirlememektedir. Birey bu bilgileri kendi zihninde değerlendirip kişisel, çevresel ve davranışsal unsurlarla birleştirerek bir sonuca ulaşmaktadır (Pajares \& Schunk, 2004). Özyeterlik inancının en güçlü kaynağı olan "bireyin kendi yaşantıları" bireyin kendi başına doğrudan yaşadığı deneyimlerdir. Birey edindiği bu deneyimler sayesinde güçlü bir özyeterlik inancı oluşturabilmektedir. Bu deneyimlerde gösterdiği başarı onun sonraki işlerde de benzer ve daha üst düzeyde başarı göstereceğine ilişkin inancını desteklemektedir (Özata, 2007). Ancak olumsuz deneyimlerin bireyin özyeterlik inancını olumsuz etkilediği de belirtilmektedir (Gençtürk, 2008). Özyeterlik inancının bir diğer kaynağı olan "dolaylı yaşantılar" bireyin başkalarının davranışlarını gözlemleyerek öğrendiğini savunmaktadır (Büyükduman, 2006). Birey gözlemlediği rol modelin davranışlarıyla kendisi arasında benzerlik kurmakta ve içselleştirmektedir (Derman, 2007; Schunk, Hanson \& Cox, 1987). Birey seçtiği rol modele ilişkin olarak kendisi ile arasında ne düzeyde benzerlik kurarsa o derece onun başarı veya başarısızlıklarından etkilenmektedir (Bandura, 1984, 1997; Senemoğlu, 2005; Woolfolk Hoy, 2000). "Sözel ikna" bireyin kendi yapabileceklerine yönelik inancı ve cesareti olarak ifade edilmektedir. Bireye yönelik olumlu iknalar onun cesaretlenerek bir işi karşı güdülenmesini arttırırken olumsuz iknalar bunun tam tersi bir etkinin oluşmasına neden olmaktadır (Bandura, 1984; Gençtürk, 2008; Milner, 2002). "Psikolojik kanıtlar" ise bireyin bir işe başladığında içinde bulunduğu psikolojik durumun performansını olumlu ya da olumsuz etkilediğini savunmaktadır (Bıkmaz, 2004). Bireyin yaşadığı üzüntü, sıkıntı, yorgunluk vb. durumların özyeterlik inançlarıyla ilgili bilgi sağlamaktadır (Pajares, 1996).

Özyeterlikle ilgili araştırmaların çeşitli bilim dallarına ayrılarak incelendiği; matematik özyeterliği, fen bilgisi özyeterliği, duygusal özyeterlik, akademik özyeterlik, sosyal özyeterlik vb. görülmektedir (Akbaş \& Çelikkaleli, 2006, s: 100). Özyeterliğin incelendiği bu alanlar arasında yer alan akademik özyeterlik bireylerin başarısı açısından oldukça önemli bulunmaktadır. Akademik özyeterlik; bireylerin gelecekle ilgili planladıkları eğitim yaşantılarında hedefledikleri başarı seviyesine erişebilmeleri için süreç içerisinde göstermeleri gereken performanslarını iyi yönetebilmeleri ve süreç boyunca gösterecekleri performanslarında başarılı olabileceklerine ilişkin kendilerine dönük algılarını ifade etmektedir (Bandura, 1997; Schunk, 1991; Zimmerman, Bandura \& Martinez-Pons, 1992). Akademik özyeterliğin akademik başarı ve performans, meslek seçimi ve öğretmen özyeterliği olarak üç temel kategoride incelendiği görülmektedir (Pajares, 1997). Bu araştırmada ele alınan akademik özyeterlik kavramı ögrencilerin bireysel olarak bir işi başarılı olarak yapabileceklerine ilişkin olarak kendilerine olan inançları olarak tanımlanmaktadır (Chun \& Choi, 2005). Akademik özyeterliğin yüksek olmasının öğrencilerin başarılarını olumlu etkilediği görülmektedir (Bandura, 1997; Pajares 1996). Bireyin öğrenmesi ve güdülenmesi üzerinde çok önemli etkileri bulunan özyeterlikle ilgili yapılan çalışmaların önemli bir kısmı öğretmen ve öğretmen adayları üzerinde gerçekleştirilmiştir. İlköğretim ve ortaöğretim öğrencilerine yönelik 
çalışmaların daha az olduğu görülmektedir. Balkıs, Duru ve Buluş’un (2005) ilköğretim ikinci kademe öğrencilerine yönelik olarak şiddete yönelik tutumları ile özyeterlik, medya, şiddete yönelik inanç, arkadaş grubu ve okula bağllılı arasındaki ilişkiyi belirlemek için yaptığı araştırma sonucunda elde edilen bulgular incelendiğinde öğrencilerin şiddete yönelik tutumlarının medya, arkadaş grubu ve şiddete yönelik inanç değişkenleriyle pozitif yönde; okula bağlılık ve özyeterlik değişkenleriyle ise negatif yönde ilişkisinin bulunduğu belirlenmiştir. Buna göre özyeterlik algısı yüksek olan öğrencilerin özyeterlik algısı düşük olan öğrencilere göre daha az şiddet eğilimlerinin olduğu söylenebilmektedir. Akar'ın (2008) özyeterlik inancının öğrencilerin ilkokuma ve yazma sürecinde başarılarını ne șekilde etkilediğini belirlemeye yönelik yaptığı araştırma sonuçları incelendiğinde; özyeterlik inançları yüksek olan öğrencilerin düşük olan öğrencilere kıyasla daha fazla çaba gösterdikleri, öğrenme konusunda daha ısrarcı oldukları ve bunun sonucu olarak da ilkokuma ve yazma sürecinde daha başarılı oldukları tespit edilmiştir. Telef ve Karaca'nın (2011) ergenlik dönemindeki öğrencilerin sahip oldukları demografik özelliklere göre özyeterlik inançlarının farklılaşıp farklılaşmadığını ve özyeterlik inançları ile psikolojik belirtileri arasında ilişki bulunup bulunmadığıı belirlemeyi amaçladığı çalışma sonuçlarına göre ergenlerin akademik, sosyal, duygusal ve genel öz-yeterlikleri ile depresyon, anksiyete (kayg1), olumsuz benlik algısı, somatizasyon (bedenselleştirme) ve hostilite (düşmanlık) arasında negatif yönde anlamlı ilişkiler saptanmıştır. Özgen ve Bindak'ın (2011) lise öğrencilerinin matematik okuryazarlığı ve matematik özyeterlik inançlarının matematik başarıları ve matematik dersine verilen önem değişkenlerine göre yordamayı amaçladığı çalışma sonuçlarına göre öğrencilerin matematik başarılarının ve matematiğe verilen önemin matematik okuryazarlığı ve matematik özyeterlik inançlarının anlamlı birer yordayıcısı oldukları tespit edilmiştir. Arslan'ın (2012) ilköğretim 6-8. Sinıf öğrencilerinin özyeterlik inanç kaynaklarının öğrenmeleri ve performansları üzerindeki etkilerini belirlemeye yönelik yaptığı çalışmaya göre öğrencilerin öğrenmeleri ve performansları üzerinde en çok etkili olan özyeterlik öğrenme kaynağının sözel ikna olduğu belirlenmiştir. Çetin'in (2013) ilkokul 4 ve 5. sınıf öğrencilerinin özyeterlik inançlarının akademik başarılarını yordamasına yönelik yaptığı çalışma sonucuna göre 4. sınıf öğrencilerinin özyeterlik puanlarının Matematik başarılarının \% 25'ini, Türkçe başarılarının \% 22'sini, Sosyal Bilgiler başarısının \% 28'ini, İngilizce başarılarının \% 19'unu; beşinci sınıf öğrencilerinin özyeterlik puanlarının Matematik başarılarının \% 19'unu, Türkçe başarılarının \% 21'ini, Sosyal Bilgiler başarılarının \%12'sini ve İngilizce başarılarının \% 18'ini açıkladığı tespit edilmiştir. Telef ve Ergün'ün (2013) lise öğrencilerinin akademik, sosyal ve duygusal özyeterliklerinin öznel olarak iyi oluşu yordayıp yordamadığını belirlemeyi amaçladığı çalışma bulgularına göre öğrencilerin bu alanlardaki yüksek özyeterlik inançlarının öznel olarak iyi oluşlarını olumlu etkilediği belirlenmiştir. Bu da özyeterlik inancının yüksek olmasının bireyin psikolojik olarak da kendini daha iyi hissetmesini desteklediği şeklinde yorumlanabilir.

Özyeterlikle ilgili pek çok çalışma bulunmasına rağmen okuma kaygısına yönelik yapılan çalışmaların nispeten az olduğu yapılan alan yazın taramasında görülmüştür. Yapılan çalışmaların çoğunlukla yabancı dil okuma kaygısı üzerine olduğu belirlenmiştir. Kuru Gönen'in (2005) İngilizceyi okullarda yabacı dil olarak öğrenen Türk öğrencilerinin görüşlerine göre öğrencilerin yabancı dilde okuma kaygısına neden olan kaynakları belirlemeyi amaçladığı çalışma bulgularına göre öğrencilerin yabancı dilde okuma kaygılarının kişisel faktörler, okuma metni ve okuma dersinden kaynaklandığı sonucuna ulaşılmıştır. Köroğlu'nun (2010) İngilizce Öğretmenliği öğrencilerinin yabancı dilde okuma ile ilgili kaygı düzeylerini ve onların hangi okuma stratejilerini kullandıklarını tespit etmek üzere yaptığı çalışma sonuçları incelendiğinde; öğrencilerin okuma kaygı seviyelerinin pek çok ülkeye göre daha yüksek olduğu, ikinci bir dilde yapılan okumanın kaygı oluşturduğu, bilinmeyen kelimeler, metnin konusuna yabancılık, açık uçlu sözlü ve yazılı soruların olması ve okunan kitapların zorluğunun öğrencilerin kaygı düzeylerini olumsuz etkilediği görülmektedir. Şahin (2011) yaptığı tez çalışmasında okuma kaygısının sebeplerini; okuma metnine yönelik alıştırmalar, öğretmenin tavrı, metnin yapısı, kişisel faktörler ve sınıf atmosferi olarak belirlemiştir. Jafarigohar ve Behrooznia (2012) tarafindan İran'da bulunan bir üniversitede öğrenim gören öğrenciler üzerinde yapılan araştırma bulgularına üniversite öğrencilerinin okuma kaygılarının okuduklarını anlamalarını olumsuz etkilediği tespit edilmiştir. Al-Shboul, Ahmad, Nordin ve Rahman (2013) tarafından öğrencilerin yabancı dilde okumaya yönelik kaygılarını belirlemek için yaptıkları nitel araştırma bulgularına göre öğrencilerin yabancı dil öğrenme kaygıları kişisel özellikler ve metnin taşıdığı özellikler olarak iki farklı boyuttan oluşmaktadır. Kişisel faktörde öne çıkan nedenler arasında hata yapmaktan korkma, okumanın etkilerini bilememenin getirdiği endişe; metin faktöründe öne çıkanlar ise kelime bilgisinin yetersizliği, yabancı oldukları bir konu ve yabancı bir kültüre ait özellikler taşıması olarak belirlenmiş̧ir. Guimba ve Alico (2015) tarafından sekizinci sınıf öğrencilerinin yabancı dilde okuma kaygılarını belirlemeye yönelik çalışma sonuçlarına göre öğrencilerin okuduklarını anlama düzeylerinin okuma kaygılarıyla negatif yönde bir ilişkinin olduğu belirlenmiştir. Hadidi ve Bargezar (2015) tarafindan yapılan okuma kaygısının öğrencilerin okuduklarını anlama ve okuma performansları üzerindeki etkisini belirlemeyi amaçlayan çalışma sonuçlarına göre okuma kaygı puanlarıyla okuma anlama ve okuma performans puanları arasında anlamlı derecede negatif yönde ilişkinin bulunduğu tespit edilmiştir. Yıldız ve Ceyhan'ın (2016) ilkokul dördüncü sınıf öğrencilerinin okuma ve yazmaya ilişkin kaygılarının çeşitli değişkenler açısından belirlenmesini ve okuma kaygısı ile yazma kaygısı arasındaki ilişkiyi belirlemek için yaptığı araştırma bulguları incelendiğinde öğrencilerin okuma kaygıları ile yazma kaygıları arasında pozitif yönde orta düzeyde bir ilişkinin olduğu görülmüştür. Bu da öğrencilerin okuma kaygıları arttıkça 
yazma kaygılarının veya yazma kaygıları arttıkça okuma kaygılarının arttığı şeklinde yorumlanabilmektedir. Altunkaya ve Erdem'in (2017) Türkçeyi yabancı dil olarak öğrenen B düzeyindeki öğrencilerin okuma kaygıları ve okuduklarını anlama becerileri arasındaki ilişkiyi belirlemeyi hedeflediği araştırma sonuçlarına göre öğrencilerin okuduğunu anlamaya yönelik yapılan başarı testinden alınan puanlarla okuma kaygı ölçeğinden alınan puanlar arasında negatif yönde düşük bir ilişkinin olduğu belirlenmiştir. Sonuçlara göre düşük düzeyde de olsa negatif yönde bir ilişskinin olması öğrencilerin okuma kaygıları arttıkça okuduğunu anlama konusunda daha düşük puanlar elde edecekleri şeklinde yorumlanmıştır. Altunkaya'nın (2017) Türkçeyi yabancı dil olarak öğrenen öğrencilerin dinleme ve okuma kaygılarını belirlemek için yaptığı araştırma bulgularına göre öğrencilerin dinleme ve okumaya ilişkin taşıdıkları kaygının orta düzeyde olduğu görülmüştür. Kaygı ve akademik özyeterlikle ilgili yapılan çalışmalar ayrıntılı olarak incelenmiş ancak akademik özyeterlik ve okuma kaygısı arasındaki ilişkiyi belirlemeye yönelik olarak yapılan bir çalışmaya rastlanılmamıştır. Bu sonuç doğrultusunda yapılan çalışmayla öğrencilerin özyeterlik inançları ve okuma kaygılarının çeşitli değişkenler açısından incelenmesi ve aralarındaki ilişkinin belirlenmesi için bu çalışmanın yapılması amaçlanmaktadır. Belirlenen bu amaca yönelik olarak aşağıdaki sorulara yanit aranacaktır:

a) Ortaokul öğrencilerinin okuma kaygıları cinsiyete, sınıf düzeyine, anne ve babanın eğitim durumuna göre anlamlı düzeyde farklılık göstermekte midir?

b) Ortaokul öğrencilerinin akademik özyeterlik inançları cinsiyete, sınıf düzeyine, anne ve babanın eğitim durumuna göre anlamlı düzeyde farklılık göstermekte midir?

c) Ortaokul öğrencilerinin okuma kaygıları ve akademik özyeterlik inançları arasında anlamlı bir ilişki bulunmakta midır?

\section{YÖNTEM}

Çalışmanın bu bölümünde evren / örneklem, veri toplama araçları, verilerin toplanması ve analizine yönelik bilgiler sunulmaktadır.

\section{Evren Örneklem}

Araştırmaya ilişkin verileri elde etmek için 2016-2017 eğitim-öğretim y1lı bahar döneminde Sivas ili Merkez ilçede eğitim bölgelerine dikkat edilerek seçilmiş 11 farklı ortaokulda öğrenim gören $241 \mathrm{klz} 255$ erkek olmak üzere toplamda 496 öğrenci çalışmaya dâhil edilmiştir. Öğrencilerin 213'ü 5. sınıf, 90'1 6. sınıf, 65'i 7. sınıf ve 128 'i 8. sınıfta öğrenim görmektedir. Araştırmaya ilişkin örneklem grubu seçilirken Sivas il merkezinde bulunan farklı eğitim bölgelerindeki okullar tercih edilmiş ve bu okullarda öğrenim görmekte olan 21.916 ortaokul öğrencisinden 0.05 anlamlılık düzeyinde $\mathrm{d}= \pm 0.05$ örnekleme hatası (Yazıcıoğlu \& Erdoğan, 2014) temel alınarak 496 öğrenci örnekleme alınmıştır. Tablo 1'de örneklem grubuna ilişkin demografik özellikler yer almaktadır.

Tablo 1.

Örnekleme İlişkin Demografik Özellikler

\begin{tabular}{llcc}
\hline Değişkenler & & Frekans (f) & Yüzde (\%) \\
\hline \multirow{2}{*}{ Cinsiyet } & Kiz & 241 & 48.6 \\
& Erkek & 255 & 51.4 \\
Sinıf & 5. Sinıf & 213 & 42.9 \\
& 6. sinıf & 90 & 18.1 \\
& 7. Sinıf & 65 & 13.1 \\
8. Sinıf & 128 & 25.8 \\
Anne Eğitim Durumu & İlkokul & 174 & 35.1 \\
& Ortaokul & 179 & 36.1 \\
& Lise & 102 & 20.6 \\
& Üniversite & 41 & 8.3 \\
\multirow{3}{*}{ Baba Eğitim Durumu } & İlkokul & 88 & 17.7 \\
& Ortaokul & 131 & 26.4 \\
& Lise & 191 & 38.5 \\
& Üniversite & 86 & 17.3 \\
\hline
\end{tabular}

\section{Veri Toplama Araçları}

Araştırmaya ilişkin verileri elde etmek için Çeliktürk ve Yamaç (2015) tarafindan ilkokul ve ortaokul öğrencilerinin okumaya yönelik kaygılarını ölçmek amacıyla geliştirilen “Okuma Kaygısı Ölçeği” ve Muris (2001) tarafindan geliştirilen Türkçeye uyarlama çalışması Telef ve Karaca (2012) tarafindan yapılan "Çocuklar İ̧̧in Özyeterlik Ölçeği” "nin alt boyutlarından olan “Akademik Öz Yeterlik Alt Ölçeği” kullanılmıştır. 


\section{Okuma Kaygısı Ölçeği}

$\mathrm{Bu}$ araştırma kapsamında Çeliktürk ve Yamaç (2015) tarafından ilkokul ve ortaokul öğrencilerinin okumaya yönelik kaygılarını ölçmek amacıyla geliştirilen Okuma Kaygısı Ölçeği kullanılmıştır. Ölçek 29 madde ve tek boyuttan oluşmaktadır. Ölçeğin toplam güvenirliği .95 olarak belirlenmiştir. Ölçek beşli likert tipinde hazırlanmış olup olumsuzdan olumluya doğru "Hiçbir zaman=1", "Çok nadiren=2", "Ara sıra=3", "Genellikle=4" ve "Her zaman=5" biçiminde puanlandırılmıştır. Bu puanlama sonucunda okuma kaygısı en yüksek olan birey 145 puan; okuma kaygısı en düşük olan birey de 29 puan alacaktır. Ölçekten alınan puanlar arttıkça öğrencilerin okuma kaygısının arttığı, azaldıkça düştüğü söylenebilir. Bu çalışma kapsamında ölçeğin güvenirliği .96 olarak tespit edilmiştir.

\section{Cocuklar İçin Özyeterlik Ölçeği / Akademik Özyeterlik Alt Ölçeği}

Öğrencilerin akademik özyeterliklerinin belirlenmesi amacıyla Muris (2001) tarafindan geliștirilen ve Türkçeye uyarlaması ise Telef ve Karaca (2012) tarafindan yapılan "Çocuklar İçin Özyeterlik Ölçeğì" kullanılmıştır. Ölçek akademik özyeterlik, sosyal özyeterlik ve duygusal özyeterlik olmak üzere üç alt boyuttan oluşmaktadır. Ölçeğin güvenirlik sonuçları incelendiğinde akademik öz-yeterlik için .84, sosyal öz-yeterlik için .64, duygusal öz-yeterlik için .78 ve ölçek toplamında ise .86 sonuçlarına ulaşııııștır. Bu araştırmada "Çocuklar İ̧̧in Özyeterlik Ölçeği”"nin yedi maddeden oluşan "Akademik Özyeterlik" alt ölçeği kullanılmıştır. Ölçek beşli likert tipinde olup "Hiç=1," "Biraz=2", "Oldukça İyi=3", "İyi=4" ve "Çok İyi=5" şeklinde derecelendirilmiştir. Bu puanlama sonucunda özyeterliği en yüksek olan birey 35 puan; özyeterliği en düşük olan birey ise 7 puan alacaktır. Ölçekten alınan puanlar arttıkça özyeterliğin de arttığı söylenebilir. Bu çalışma kapsamında ölçeğin güvenirliği .82 olarak tespit edilmiştir.

\section{Verilerin Toplanması ve Analizi}

Araştırma için Sivas il merkezinde bulunan farklı eğitim bölgelerinde bulunan 11 farklı ortaokul belirlenmiş ve uygulama için gerekli izinler alınmıştır. Ölçekler 2016-2017 eğitim-öğretim yılı bahar döneminde $5,6,7$ ve 8. sınıf düzeyindeki 518 öğrenciye uygulanmıştır. Ancak uygulanan ölçeklerin 22 tanesinin gerekli özellikleri içermediği belirlenerek araştırmadan çıkarılmış ve kalan 496 ölçek üzerinden analizler yapılmıştır.

\section{Verilerin Analizi}

Verilerin analizi için SPSS 22.0 istatistik programı kullanılmıştır. Puanların normal dağılımını belirlemek amacıyla Kolmogorov-Smirnov (K-S) Testi uygulanmıştır. Verilerin normallik analizleri yapılarak aritmetik ortalama ve standart sapma puanlarına bakılmıştır. Bu testlerin sonucuna göre; öğrencilerin okuma kaygıları ve özyeterlik inançlarının cinsiyet, sınıf, anne ve baba eğitim durumlarına göre anlamlı olarak farklılaşıp farklılaşmadığını belirlemek için Anova ve bağımsız T testi kullanılmıştır. Yapılan Anova testi sonuçlarında anlamlı farklıların olduğu görülmüş̧ür. Bu farklılıkların hangi gruplar arasında olduğunun tespiti için ise LSD testi uygulanmıştır. Öğrencilerin okuma kaygı puanları ile akademik özyeterlik puanları arasındaki ilişki düzeyinin belirlenmesi amacıyla Spearman Brown Korelasyon Katsayısı kullanılmıştır.

\section{BULGULAR}

Bu çalışma kapsamında elde edilen verilerin analiz edilmesiyle elde edilen bulgular, araştırma sorularının sırasına uygun olarak aşağıda sunulmaktadır. Ortaokul öğrencilerinin cinsiyet değişkenine göre okuma kaygılarının belirlenmesi için uygulanan bağımsız $\mathrm{t}$ testi sonucunda ulaşılan bulgular Tablo 2'de verilmektedir.

Tablo 2 .

Ortaokul Öğrencilerinin Cinsiyet Değişkenine Göre Okuma Kaygıları Bağımsız T Testi Bulguları

\begin{tabular}{lllllll}
\hline & Cins. & N & Ort. & ss & t & p \\
\hline \multirow{2}{*}{ Okuma kaygis1 } & Kiz & 241 & 114.69 & 26.44 & \multirow{2}{*}{1.19} & .24 \\
\hline p .05 & Erkek & 255 & 117.53 & 27.02 & & \\
\end{tabular}

Tablo 2'de yer alan bulgular incelendiğinde ortaokul öğrencilerinin cinsiyet değişkenine göre okuma kaygı puanlarının anlamlı olarak farklılık göstermediği $p>.05$ tespit edilmiştir. Ancak elde edilen bulgular incelendiğinde kız öğrencilerin erkek öğrencilerden daha düşük okuma kaygısı taşıdıkları görülmektedir.

Ortaokul öğrencilerinin sınıf değişkenine göre okuma kaygılarını belirlemek için uygulanan Anova testi sonucunda ulaşılan bulgular Tablo 3’te sunulmuştur.

Tablo 3.

Ortaokul Ögrrencilerinin Stnıf Düzeyi Değişkenine Göre Okuma Kaygıları Anova Testi Bulguları 


\begin{tabular}{rcrccccc}
\hline & Sinıf & N & Ortalama & Ss & F & p & $\begin{array}{c}\text { Anlaml Fark } \\
\text { LSD }\end{array}$ \\
\hline & 5.Sinıf & 213 & 114.78 & 27.31 & & & $* 5-7, * 5-8$, \\
Okuma kaygis1 & 6.Sinif & 90 & 119.88 & 24.24 & 5.08 & .00 & $* 6-7, * 7-8$ \\
& 7.Sinif & 65 & 106.35 & 32.60 & & & \\
\hline
\end{tabular}

$* \overline{\mathrm{p}<.05}$

Tablo 3'te yer alan bulgular incelendiğinde ortaokul öğrencilerinin sınıf düzeyi değişkenine göre okuma kaygılarında anlamlı farklılık $\mathrm{p}<.05$ olduğu görülmektedir. Bu farklılığın hangi gruplar arasında olduğunu belirlemek için yapılan LSD testinde "5 ve 7", "5 ve 8", "6 ve 7", "7 ve 8." sinıflar arasinda anlamlı farklılık olduğu tespit edilmiştir. En düşük okuma kaygısını yedinci sınıf öğrencilerinin en yüksek okuma kaygısını ise sekizinci sınıf öğrencilerinin taşıdıkları görülmektedir.

Ortaokul öğrencilerinin anne eğitim durumu değişkenine göre okuma kaygılarını tespit etmek amacıyla uygulanan Anova testi sonucunda ulaşılan bulgular Tablo 4'te sunulmuştur.

Tablo 4.

Ortaokul Öğrencilerinin Annenin Eğitim Durumu Değişkenine Göre Okuma Kaygıları Anova Testi Bulguları

\begin{tabular}{llcccccc}
\hline & Sinıf & N & Ortalama & SS & F & p & Anlaml Fark LSD \\
\hline \multirow{4}{*}{ Okuma kaygisı } & İlkokul & 174 & 115.61 & 28.57 & & & \\
& Ortaokul & 179 & 114.07 & 25.08 & 1.09 & .35 & Yok \\
& Lise & 102 & 119.56 & 27.22 & & & \\
\hline
\end{tabular}

$\mathrm{p}>.05$

Tablo 4'te yer alan bulgular incelendiğinde ortaokul öğrencilerinin annenin eğitim durumu değişkenine göre okuma kaygılarında anlamlı farklılık p>.05 olmadığı belirlenmiştir. Ancak bulgular incelendiğinde okuma kaygısı puanları en düşük olan öğrencilerin anne eğitim düzeyi üniversite olan öğrenciler olduğu; okuma kaygısı en yüksek olan öğrencilerinse anne eğitim durumu ilkokul olan öğrenciler olduğu görülmektedir.

Ortaokul öğrencilerinin baba eğitim durumu değişkenine göre okuma kaygılarına ilişkin uygulanan Anova testi sonucunda ulaşılan bulgular Tablo 5'te sunulmuştur.

Tablo 5.

Ortaokul Öğrencilerinin Babanın Eğitim Durumu Değişkenine Göre Okuma Kaygıları Anova Testi Bulguları

\begin{tabular}{|c|c|c|c|c|c|c|c|}
\hline & Sinıf & $\mathbf{N}$ & Ortalama & SS & $\mathbf{F}$ & $\bar{p}$ & Anlamlı Fark LSD \\
\hline \multirow[t]{4}{*}{ Okuma kaygısı } & İlkokul & 88 & 111.41 & 31.08 & \multirow{4}{*}{1.87} & \multirow{4}{*}{$.03 *$} & \multirow{4}{*}{ *İlkokul-Üniversite } \\
\hline & Ortaokul & 131 & 114.85 & 26.24 & & & \\
\hline & Lise & 191 & 117.33 & 26.60 & & & \\
\hline & Üniversite & 86 & 120.37 & 22.31 & & & \\
\hline
\end{tabular}

Tablo 5'te yer alan bulgular incelendiğinde ortaokul öğrencilerinin babanın eğitim durumu değişkenine göre okuma kaygılarında anlamlı farklılık p <.05 olduğu görülmektedir. Bu farklılığın hangi gruplar arasında olduğunu belirlemek için yapılan LSD "ilkokul ve üniversite", grupları arasında anlamlı farklılığın olduğu görülmektedir. Anlamlı farklılığın ilkokul baba eğitim durumu lehine olduğu görülmektedir. Elde edilen bulgulara göre en yüksek okuma kaygısını baba eğitim durumu üniversite olan öğrencilerin en düşük okuma kaygısını ise baba eğitim durumu ilkokul olan öğrencilerin taşıdıkları görülmektedir.

Ortaokul öğrencilerinin cinsiyet değişkenine akademik özyeterlik inançlarına ilişkin uygulanan bağımsız t testi sonucunda ulaşılan bulgular Tablo 6'da sunulmuştur.

Tablo 6.

Ortaokul Öğrencilerinin Cinsiyet Değişkenine Göre Akademik Özyeterlik Bağımsız T Testi Bulguları

\begin{tabular}{lllllll}
\hline & Cins. & N & Ort. & ss & t & p \\
\hline \multirow{2}{*}{ Akademik özyeterlik } & Kiz & 241 & 27.38 & 5.26 & \multirow{2}{*}{1.38} & .17 \\
& Erkek & 255 & 26.71 & 5.52 & & \\
\hline
\end{tabular}

$\mathrm{p}>.05$ 
Tablo 6'da yer alan bulgular incelendiğinde ortaokul öğrencilerinin cinsiyet değişkenine göre akademik özyeterlik puanlarının anlamlı olarak farklılık göstermediği tespit edilmiştir. Fakat bulgular incelendiğinde kız öğrencilerin akademik özyeterlik puanlarının erkek öğrencilerin akademik özyeterlik puanlarından daha yüksek olduğu görülmektedir.

Ortaokul öğrencilerinin sınıf düzeyi değişkenine akademik özyeterlik inançlarına ilişkin uygulanan Anova testi sonucunda ulaşılan bulgular Tablo 7'de sunulmuştur.

Tablo 7.

Ortaokul Öğrencilerinin Sinıf Düzeyi Değiş̧kenine Göre Akademik Özyeterlik Anova Testi Bulguları

\begin{tabular}{rcrccccc}
\hline & Sinıf & \multicolumn{1}{c}{ N } & Ortalama & ss & F & p & $\begin{array}{c}\text { Anlamlı Fark } \\
\text { LSD }\end{array}$ \\
\hline \multirow{3}{*}{ Akademik } & 5.Sinıf & 213 & 29.21 & 4.35 & & & $* 5-6, * 5-7$, \\
özyeterlik & 6.Sinıf & 90 & 26.80 & 5.26 & 32.90 & .00 & $* 5-8, * 6-8$, \\
& 7.Sinıf & 65 & 26.78 & 5.02 & & & $* 7-8$ \\
\hline
\end{tabular}

$* \overline{\mathrm{p}<.05}$

Tablo 7'de yer alan bulgular incelendiğinde ortaokul öğrencilerinin sınıf düzeyi değişkenine göre akademik özyeterlik puanlarında anlamlı farklılık $\mathrm{p}<.05$ olduğu görülmektedir. Bu farklılığın hangi gruplar arasında olduğunu belirlemek için yapılan LSD testinde "5 ve 6", "5 ve 7", "5 ve 8", "6 ve 8", "7 ve 8" sinıfları arasında anlamlı farklılık olduğu tespit edilmiştir. Alt sınıftaki öğrencilerin üst sınıftaki öğrencilere göre daha fazla akademik özyeterliğe sahip oldukları görülmektedir. En yüksek akademik özyeterliğe 5. Sinıf öğrencilerinin en düşük akademik özyeterliğe ise 8 . Sınıf öğrencilerinin sahip oldukları görülmektedir.

Ortaokul ögrencilerinin annenin eğitim durumu değişkenine akademik özyeterlik inançlarına ilişkin uygulanan Anova testi sonucunda ulaşılan bulgular Tablo 8'de sunulmuştur.

Tablo 8.

Ortaokul Öğrencilerinin Annenin Ĕ̈itim Durumu Değişkenine Göre Akademik Özyeterlik Anova Testi Bulguları

\begin{tabular}{llrccccc}
\hline & SInıf & N & Ortalama & Ss & F & p & Anlamlı Fark LSD \\
\hline \multirow{3}{*}{ Akademik } & İlkokul & 174 & 26.59 & 5.68 & & & $*$ \\
özyeterlik & Ortaokul & 179 & 26.74 & 5.23 & 2.25 & $.04 *$ & *Ilkokul-Lise \\
& Lise & 102 & 28.20 & 4.50 & & & \\
& Üniversite & 41 & 27.37 & 6.60 & & & \\
\hline
\end{tabular}

$* \bar{p}<.05$

Tablo 8'de yer alan bulgular incelendiğinde ortaokul öğrencilerinin annenin eğitim durumu değişkenine göre akademik özyeterlik inançlarında anlamlı farklılık $\mathrm{p}<.05$ olduğu görülmektedir. Bu farklılığın hangi gruplar arasında olduğunu belirlemek için yapılan LSD testinde "ilkokul ve lise", "ortaokul ve lise" grupları arasında anlamlı farklılık olduğu belirlenmiştir. Anlamlı farklılığın daha üst seviyedeki anne eğitim durumu lehine olduğu görülmektedir. Anne eğitim durumuna göre en düşük akademik özyeterliğe sahip öğrencilerin ilkokul en yüksek öğrencilerin ise lise eğitim seviyesi olduğu tespit edilmiştir.

Ortaokul öğrencilerinin babanın eğitim durumu değişkenine akademik özyeterlik inançlarına ilişkin uygulanan Anova testi sonucunda ulaşılan bulgular Tablo 9'da sunulmuştur.

Tablo 9.

Ortaokul Öğrencilerinin Babanın Eğitim Durumu Değişkenine Göre Akademik Özyeterlik Anova Testi Bulguları

\begin{tabular}{llrccccc}
\hline & Sinıf & N & Ortalama & Ss & F & p & Anlamlı Fark LSD \\
\hline & İlkokul & 88 & 27.16 & 5.34 & & & \\
Akademik & Ortaokul & 131 & 25.88 & 5.39 & 3.32 & $.02 *$ & *Ortaokul-Lise \\
özyeterlik & Lise & 191 & 27.29 & 5.50 & & & * Ortaokul-Üniversite \\
& Üniversite & 86 & 28.12 & 5.05 & & & \\
\hline
\end{tabular}

$* \overline{\mathrm{p}<.05}$

Tablo 9'da yer alan bulgular incelendiğinde ortaokul öğrencilerinin babanın eğitim durumu değişkenine göre akademik özyeterlik inançlarında anlamlı farklılık $\mathrm{p}<.05$ olduğu görülmektedir. Bu farklılığın hangi gruplar arasında olduğunu belirlemek için yapılan LSD testinde "ortaokul ve lise", "ortaokul ve üniversite" grupları arasında anlamlı farklılık olduğu belirlenmiștir. Bu farklılı̆ın daha üst seviyedeki baba eğitim durumu lehine olduğu tespit edilmiştir. Baba eğitim durumuna göre en düşük özyeterliğe sahip öğrencilerin ortaokul en yüksek öğrencilerinse üniversite düzeyi olduğu görülmektedir. 
Ortaokul öğrencilerinin okuma kaygıları ve akademik özyeterlik inançları arasındaki ilişkinin belirlenmesi amacıyla ilişki analizi yapılmıştır. Analiz sonucunda elde edilen bulgular Tablo 10' da yer almaktadır.

Tablo 10.

Ortaokul Öğrencilerinin Okuma Kaygıları ve Akademik Özyeterlik Inançları Arasındaki Korelasyon Testi Sonuçları

\begin{tabular}{lcc}
\hline & Okuma Kaygısı & Akademik Özyeterlik \\
\hline Okuma Kaygısı & 1 & $-.34^{*}$ \\
Akademik Özyeterlik & $-.34^{*}$ & 1 \\
\hline
\end{tabular}

Tablo 10'a göre ortaokul öğrencilerinin okuma kaygıları ile akademik özyeterlik inançları arasında orta düzeyde $(\mathrm{r}=-.34)$ negatif yönde orta düzeyde ilişkinin bulunduğu görülmektedir.

\section{TARTISMA, SONUC VE ÖNERILER}

Araştırmanın bu bölümünde ortaokul öğrencilerinin okuma kaygılarına ve akademik özyeterliklerine ilişkin puanların cinsiyet, sınıf düzeyi, anne ve babanın eğitim durumu değişkenlerine dönük bulgulara ve okuma kaygıları ile akademik özyeterlikleri arasındaki ilişkinin bulgularına yer verilmektedir. Elde edilen bulgular ilgili alan yazın dikkate alınarak tartışılmış ve bir sonuca ulaşılmıştır.

Ortaokul öğrencilerinin cinsiyet değişkenine göre okuma kaygı puanlarının anlamlı olarak farklılık p >.05 göstermediği tespit edilmiştir. Ancak elde edilen bulgular incelendiğinde kız öğrencilerin erkek öğrencilerden daha düşük okuma kaygısı taşıdıkları görülmektedir. Altunkaya'nın (2017) Türkçeyi yabancı dil olarak öğrenenlerin dinleme ve okuma kaygılarını belirlemek amacıyla yaptığı araştırma bulgularına göre okuma kaygı seviyelerinin orta düzeyde bulunduğu ve okuma kaygılarının cinsiyet değişkeni açısından anlamlı bir şekilde farklılaşmadığı tespit edilmiştir. Kılınç ve Yenen'in (2016) yaptıkları çalışma sonucunda cinsiyet değişkeninin okuma kaygısını etkilemediği görülmüştür. Yıldız ve Ceyhan'ın (2016) ilkokul dördüncü sınıf düzeyinde yaptıkları araştırma bulgularına göre de cinsiyet değişkeni ile okuma kaygısı arasında anlamlı farklılık bulunmamıştır. Elde edilen sonuçlar yapılan bu araştırma sonuçlarını desteklemektedir. Sert'in (2010) 6. sınıf düzeyindeki öğrencilere yönelik yaptığı araştırma bulgularına göre öğrencilerin okuduğunu anlama ve kaygı seviyelerinin cinsiyet değişkeni ile anlamlı farklılığın bulunduğu belirlenmiştir. Jafarigohar ve Behrooznia (2012) tarafindan İran'da bulunan bir üniversitedeki öğrencilerin yabancı dilde okuma kaygıları ve anlama düzeylerini belirlemek için yaptığı araştırma bulgularına göre cinsiyet değişkenine göre erkekler lehine olmak üzere anlamlı farklılığın bulunduğu tespit edilmiştir. Genç'in (2016) yaptığı araştırmanın sonuçları incelendiğinde yine cinsiyet değişkeninin okuma kaygısı üzerinde etkili olduğu tespit edilmiştir. Kuşdemir ve Katrancı’nın (2016) ilkokul dördüncü sınıf düzeyinde yaptığ araştırma bulgularına göre öğrencilerin okuma kaygılarının cinsiyete göre farklılık gösterdiği ve bu farklılığın kızlar lehine olduğu sonucuna ulaşılmıştır. Görüldüğü gibi öğrencilerin cinsiyetlerinin okuma kaygılarını nasıl etkilediğine ilişkin farklı sonuçlar elde edilmiştir.

Ortaokul öğrencilerinin sınıf düzeyi değişkenine göre okuma kaygılarında anlamlı farklılık *p<.05 olduğu görülmektedir. Bu farklılığın hangi gruplar arasında olduğunu belirlemek için yapılan LSD testinde "5 ve 7", "5 ve 8", "6 ve 7", "7 ve 8" sınıfları arasında anlamlı farklılık olduğu tespit edilmiştir. En düşük kaygıya yedinci sınıf öğrencilerinin en yüksek kaygıya ise sekizinci sınıf öğrencilerinin sahip oldukları görülmektedir. Kılınç ve Yenen'in (2016) yaptıkları çalışma sonuçları incelendiğinde sınıf düzeyi değişkeninin öğrencilerin okuma kaygıları üzerinde anlamlı farklılık oluşturduğu ve öğrencilerin okuma kaygılarının sınıf seviyesi yükseldikçe arttığı belirlenmiştir. Köroğlu'nun (2010) üniversite öğrencileri üzerinde yaptığı tez çalışması sonuçlarında da bu çalışmayla uyumlu olarak anlamlı farklılığın olduğu görülmüştür. Elde edilen bu sonuçlar birlikte değerlendirildiğinde öğrencilerin sınıf seviyeleri yükseldikçe okuma kaygılarının arttığı görülmektedir.

Ortaokul öğrencilerinin annenin eğitim durumu değişkenine göre okuma kaygılarında anlamlı farklılık p>.05 olmadığı görülmektedir. Ancak bulgular incelendiğinde en düşük okuma kaygısı düzeyine anne eğitim durumu üniversite olan öğrencilerin durumuna sahip olan öğrencilerin en yüksek okuma kaygısı düzeyine ise anne eğitim durumu ilkokul olan öğrencilerin olduğu görülmektedir. Yıldız ve Ceyhan'ın (2016) araştırma bulgularına göre anne eğitim durumunun öğrencilerin okuma kaygıları üzerinde anlamlı farklılık oluşturmadığı belirlenmiştir. Kuşdemir ve Katrancı'nın (2016) çalışma sonuçlarına göre annenin eğitim durumunun okuma kaygısını etkilediği tespit edilmiştir. Annenin eğitim düzeyi yükseldikçe öğrencinin okuma kaygısının azaldığı görülmektedir.

Ortaokul öğrencilerinin babanın eğitim durumu değişkenine göre okuma kaygılarında anlamlı farklılık *p<.05 olduğu görülmektedir. Bu farklılı̆̆ın hangi gruplar arasında olduğunu belirlemek için yapılan LSD “ilkokul ve üniversite", grupları arasında anlamlı farklılığın olduğu görülmektedir. Anlamlı farklılığın daha ilkokul baba eğitim durumu lehine olduğu görülmektedir. Elde edilen bulgulara göre en yüksek okuma kaygısına baba eğitim durumu üniversite olan öğrencilerin en düşük okuma kaygısına ise baba eğitim durumu ilkokul olan öğrencilerin 
sahip oldukları görülmektedir. Kuşdemir ve Katrancı'nın (2016) ilkokul dördüncü sınıf seviyesinde yaptı̆g 1 çalışma sonucuna göre öğrencilerin okuma kaygıları üzerinde babanın eğitim durumu etkili olmaktadır. Ulaşılan sonuç bu çalışmayla paralellik göstermektedir. Yıldız ve Ceyhan'ın (2016) çalışma sonucunda ise babanın eğitim durumunun öğrencilerin okuma kaygısını etkilemediği belirlenmiştir.

Ortaokul öğrencilerinin cinsiyet değişkenine göre akademik özyeterlik puanlarının anlamlı olarak farklılık p>.05 göstermediği tespit edilmiştir. Fakat bulgular incelendiğinde kız öğrencilerin nispeten erkek öğrencilerde daha yüksek akademik özyeterliğe sahip oldukları görülmektedir. Akbaş ve Çelikkaleli’nin (2006) sınıf öğretmeni adayları üzerinde yaptığı araştırma bulgularında bu araştırma sonucuyla uyumlu olarak özyeterlik inançlarının cinsiyet değişkenine göre farklılaşmadığı belirlenmiştir. Çetin'in (2009) ilköğretim dördüncü ve beşinci sınıf öğrencileri üzerinde yaptığı araştırma bulgularında da cinsiyet değişkeninin özyeterlik puanları üzerinde anlamlı farklılık oluşturmadığı tespit edilmiştir. Akçay ve Akkuzu'nun (2012) kimya öğretmen adaylarının özyeterliklerini yaptığı çalışma sonucunda da cinsiyet değişkenine göre anlamlı farklılık olmadığı belirlenmiştir. İnnalı ve Aydın'ın (2014) ilköğretim sekizinci sınıf seviyesinde yaptığı araştırma bulgularına göre öğrencilerin özyeterlik puanları cinsiyet değişkenine göre anlamlı farklılık göstermekte ve bu farklılık kız öğrenciler lehine olmaktadır. Koç ve Arslan'ın (2017) ortaokul öğrencilerine yönelik yaptıkları araştırma bulgularının sonuçlarında da kız öğrenciler lehine anlamlı farklılı̆̆ın olduğu belirlenmiştir.

Ortaokul öğrencilerinin sınıf düzeyi değişkenine göre akademik özyeterlik puanlarında anlamlı farklılık ${ }^{*} \mathrm{p}<.05$ olduğu görülmektedir. Bu farklıllğın hangi gruplar arasında olduğunu belirlemek için yapılan LSD testinde "5 ve 6", "5 ve 7", "5 ve 8", "6 ve 8", "7 ve 8" sinıfları arasında anlamlı farkl1lık olduğu tespit edilmiştir. Alt sınıftaki öğrencilerin üst sınıftaki öğrencilere göre daha fazla akademik özyeterliğe sahip oldukları görülmektedir. En yüksek akademik özyeterliğe 5. sınıf öğrencilerinin en düşük akademik özyeterliğe ise 8. sinıf öğrencilerinin sahip oldukları görülmektedir. Baykara'nın (2011) öğretmen adayları üzerinde yaptığı araştırma bulgularına göre öğrencilerin özyeterlik puanlarının sınıf düzeyi değişkenine anlamlı farklılık gösterdiği tespit edilmiştir. Altıntaş, Özdemir ve Kerpiç’in (2012) yaptığı çalışma sonuçlarına göre öğrencilerin özyeterlik inançları sınıf düzeyi değişkenine göre anlamlı farklılık göstermektedir. Koç ve Arslan'ın (2017) yaptıkları araştırma sonuçlarına göre de sınıf düzeyi değişkenine göre anlamlı farklılı̆̆ın olduğu ve bu farklılığın yine bu çalışmayla uyumlu olarak alt düzeydeki sınıflar lehine olduğu görülmektedir. Akçay ve Akkuzu'nun (2012) kimya öğretmen adaylarının özyeterliklerini yaptığı çalışma sonucu incelendiğinde sınıf değişkenine göre anlamlı farklılık olmadığı belirlenmiştir.

Ortaokul ögrencilerinin annenin eğitim durumu değişkenine göre akademik özyeterlik inançlarında anlamlı farklılık *p<.05 olduğu görülmektedir. Bu farklılığın hangi gruplar arasında olduğunu belirlemek için yapılan LSD testinde "ilkokul ve lise", "ortaokul ve lise" grupları arasında anlamlı farklılık olduğu belirlenmiştir. Anlamlı farklılığın daha üst seviyedeki anne eğitim durumu lehine olduğu görülmektedir. Anne eğitim durumuna göre en düşük akademik özyeterliğe sahip öğrencilerin ilkokul en yüksek öğrencilerin ise lise eğitim seviyesi olduğu tespit edilmiştir. İnnalı ve Aydın'ın (2014) araştırmaları sonucu bu çalışma sonucunu destekler nitelikte olup anne eğitim durumunun özyeterlik puanlarını anlamlı olarak farklılaştırdığı görülmüşsür. Annenin eğitim durumu yükseldikçe öğrencinin özyeterlik puanlarında artış olduğu belirlenmiştir. Koç ve Arslan'ın (2017) yaptıkları araştırma bulguları incelendiğinde öğrencilerin akademik özyeterlik puanlarının annenin eğitim durumu değişkenine göre anlamlı farklılık gösterdiği ve bu farklılı̆̆ın üst düzey anne eğitim durumu lehine olduğu görülmektedir.

Çetin'in (2009) araştırmasından elde edilen bulgular incelendiğinde anne eğitim durumunun anlamlı farklılık oluşturmadığı görülmüştür.

Ortaokul öğrencilerinin babanın eğitim durumu değişkenine göre akademik özyeterlik inançlarında anlamlı farklılık * $<.05$ olduğu görülmektedir. Bu farklılığın hangi gruplar arasında olduğunu belirlemek için yapılan LSD testinde "ortaokul ve lise", "ortaokul ve üniversite" grupları arasında anlamlı farklılık olduğu belirlenmiştir. Bu farklılığın daha üst seviyedeki baba eğitim durumu lehine olduğu tespit edilmiştir. Baba eğitim durumuna göre en düşük özyeterliğe sahip öğrencilerin ortaokul en yüksek öğrencilerinse üniversite düzeyi olduğu görülmektedir. İnnalı ve Aydın'ın (2014) yaptığı araştırma bulgularında baba eğitim durumunun öğrencilerin özyeterlik puanları üzerinde etkisinin olduğu tespit edilmiştir. Baba eğitim seviyesi arttıkça öğrencinin özyeterlik puanlarının anlamlı olarak arttı̆̆ görülmektedir. Koç ve Arslan'ın (2017) yaptıkları araştırma bulguları incelendiğinde öğrencilerin akademik özyeterlik puanlarının babanın eğitim durumu değişkenine göre anlamlı farklılık gösterdiği ve bu farklılığın üst düzey baba eğitim durumu lehine olduğu görülmektedir. Çetin'in (2009) yaptığı çalışmaya göre baba eğitim durumu özyeterlik puanları arasında anlamlı farklılık oluşturmamaktadır.

Ortaokul öğrencilerinin okuma kaygıları ile akademik özyeterlik inançları arasında ise orta düzeyde $(\mathrm{r}=-$ .34) negatif yönde orta düzeyde ilişki bulunmaktadır. İlişkinin negatif yönde çıkması öğrencilerin akademik özyeterliği arttıkça okuma kaygılarının düştüğü şeklinde yorumlanabilir.

Yapılan alan yazın taramasında dilin temel becerileri arasında yer alan okuma üzerinde farklı konularda pek çok farklı çalışmanın bulunduğu belirlenmiştir. Ancak okuma kaygısına ilişkin olarak yapılan çalışmaların oldukça sınırlı olduğu belirlenmiştir. Bu bağlamda okuma kaygısına yönelik olarak daha fazla çalışmanın yapılması gerektiği düşünülmektedir. Yapılan çalışma çerçevesinde şu öneriler sunulmaktadır: 
Yapılan bu çalışmada akademik özyeterlik inancının okuma kaygısını olumlu etkilediği belirlenmiştir. Diğer üstbilişsel becerilerin ve yapılandırmacı eğitim sistemi içerisindeki yöntem ve tekniklerin etkin olarak kullanılması, okuma kaygısı üzerindeki etkilerinin belirlenmesi gerekmektedir.

Okuma kaygısı üzerine yapılan çalışmalarda nitel ve nicel yöntemlerin birlikte kullanılması daha detaylı ve derinlikli bilgiler elde edilebilir.

Okuma kaygısının farklı okul türleri ve farklı eğitim seviyelerinde farklı değişkenlerle yapılmasının alan yazının gelişmesini destekleyeceği düşünülmektedir.

Okuma kaygısının temelinde yatan nedenler üzerinde daha fazla çalışma yapılması gerekmektedir. Bunun için de rehberlik birimleriyle yapılacak ortak çalışmaların sonuçları yapılan diğer çalışmalarla birlikte değerlendirilmelidir.

\section{KAYNAKÇA}

Acar, T. (2005). Öz yeterlilik (self-efficacy) kavramı üzerine. Erişim tarihi: 02 Ağustos 2017, http://docplayer.biz.tr/2094979-Oz-yeterllk-self-effcacy-kavrami-uzerne-tulin-acar.html.

Açıkgöz, Ü. K. (1996). Etkili ögrenme ve ögretme. İzmir: Kanyılmaz Matbaası.

Akar, C. (2008). Öz-Yeterlik inanc1 ve ilkokuma yazmaya etkisi. Uşak University Journal of Social Sciences, 1(2), 185-198.

Akbaş, A., \& Çelikkaleli, Ö. (2006). Sınıf öğretmeni adaylarının fen öğretimi özyeterlik inançlarının cinsiyet, öğrenim türü ve üniversitelerine göre incelenmesi. Mersin Üniversitesi Ĕ̈itim Fakültesi Dergisi, 2(1), 98-110.

Akçay, H., \& Akkuzu, N. (2012). Kimya öğretmen adaylarının öz yeterlik inançlarının farklı değişkenler açısından incelenmesi (Dokuz Eylül Üniversitesi örneği). Kuram ve Uygulamada Ĕ̆itim Bilimleri, 12, 2195-2216.

Akyol H. (2007). Görsel okuma. A. Kırkkılıç ve H. Akyol (Ed.), İlkögrretimde Türkçe Öğretimi içinde. Ankara: Pegem A Yayıncılık.

Akyol, H. (2011). Türkçe ögretim yöntemleri. (4. Baskı). Ankara: Pegem A Yayıncılık.

Al-Shboul, M. M., Ahmad, I. S., Nordin, M. S., \& Rahman, Z. A. (2013). Foreign language reading anxiety in a Jordanian EFL context: A qualitative study. English Language Teaching, 6(6), 38-56. DOI: 10.5539/elt.v6n6p38

Altıntaş, E., Özdemir, A. Ş., \& Kerpiç, A. (2012). Öğretmen adaylarının matematik okuryazarlığı özyeterlik algılarının bölümlere göre karşılaştırılması. Trakya Üniversitesi Eğitim Fakültesi Dergisi, 2(2), 26-34.

Altunkaya, H. (2015). Yabancı dil olarak Türkçe öğrenenlerin okuma kaygıları ile okuduğunu anlama becerileri arasındaki ilişki. Yayımlanmamış Doktora Tezi. İnönü Üniversitesi Eğitim Bilimleri Enstitüsü, Malatya.

Altunkaya, H. (2017). Yabancı dil olarak Türkçe öğrenenlerin dinleme ve okuma kaygıları. Education Sciences (NWSAES), 12(3), 107-121, DOI: 10.12739/NWSA.2017.12.3.1C0672.

Altunkaya, H., \& Erdem, İ. (2017). Yabancı dil olarak Türkçe öğrenenlerin okuma kaygıları ve okuduğunu anlama becerileri. Sakarya University Journal of Education, 7(1), 59-77. DOI: 10.19126/suje.307045

Alvermann, D. E., \& Guthrie J. T. (1993). Themes and directions of the national reading research center (Perspectives in Reading Research No. 1). Athens, GA: National Reading Research Center.

Andrade, M., \& Williams, K. (2009). Foreign language learning anxiety in japanese EFL universty classes: physical, emotional, expressive and verbal reactions. Sophia Junior College Faculty Journal, 29, 1-24.

Arslan, A. (2012). İlköğretim öğrencilerinin öz yeterlik inancı kaynaklarının öğrenme ve performansla ilgili öz yeterlik inancını yordama gücü. Kuram ve Uygulamada Ĕ̈itim Bilimleri, 12(3), 1907-1920.

Balkıs, M., Duru, E., \& Buluş, M. (2005). Şiddete yönelik tutumların özyeterlik medya şiddete yönelik inanç arkadaş grubu ve okula bağlılık duygusu ile ilişkisi. Ege Eğitim Dergisi, 6(2), 81-97.

Bandura, A. (1977). Social learning theory. Englewood Cliffs, NJ: Prentice Hall.

Bandura, A., \& Adams, N. E. (1977). Analysis of self-efficacy theory of behavioral change. Cognitive Therapy and Research, 1, 287-308. DOI: http://dx.doi.org/10.1007/BF01663995

Bandura, A. (1984). Recycling misconceptions of perceived self efficacy. Cognitive Therapy and Research, 8(3). 231-255. DOI: http://dx.org/10.1007/BF01172995

Bandura, A. (1986). Social foundation of thought and action: A social cognitive theory. Englewood Cliffs, NJ: Prentice Hall.

Bandura, A. (1997). Self efficacy: The exercise of control. New York: W. H. Freeman and Company.

Bandura, A. (2001). A cognite theory: an agentic perspective. Annual Review of Psychology, 52, 1-26. DOI: 10.1146/annurev.psych.52.1.1

Bamberger, R. (1990). Okuma alışkanlı̆̆ını geliştirme. Bengü Çapar (Çev.). Ankara: Kültür Bakanlığı Yayınları.

Baykara, K. (2011). Öğretmen adaylarının bilişötesi öğrenme stratejileri ile öğretmen yeterlik algıları üzerine bir çalışma. Hacettepe Üniversitesi Ĕ̈itim Fakültesi Dergisi, 40(40), 80-92.

Bıkmaz, F. H. (2004). Sınıf öğretmenlerinin fen öğretiminde öz yeterlik inancı ölçeğinin geçerlik ve güvenirlik çalışması. Milli Eğitim Dergisi. 161. Erişim tarihi: 02 Ağustos 2017, http://dhgm.meb.gov.tr/yayimlar/dergiler/milli_egitim_dergisi/161/bikmaz.htm. 
Binbaşıŏlu, C. (1973). Özel öğretim metotları. Ankara: Binbaşığlu Yayınevi.

Büyükduman, F. İ. (2006). İngilizce öğretmen adaylarının İngilizce ve öğretmenlik becerilerine ilişskin öz yeterlik inançları arasındaki ilişski. Yayımlanmamış Doktora Tezi. Yıldız Teknik Üniversitesi Sosyal Bilimler Enstitüsü, İstanbul.

Chapman W. J., \& Tunmer E. W. (2003). Reading difficulties, readingrelated self-perceptions, and strategies for overcoming negative self beliefs. Reading \& Writing Quartely, 19, 5-24. DOI: http://dx.doi.org/10.1080/10573560308205

Chun, A. H. C., \& Choi, J. N. (2005). Rethinking procrastination: Positive effects of "active" procrastination behavior on attitudes and performance. The Journal of Social Psychology, 145, 245-264. DOI: 10.3200/SOCP.145.3.245-264

Coltheart, M. (2005). Comprehension instruction: Research-based best practices. Margaret J. Snowling \& Charles Hulme (Eds.). In the science of reading: A handbook. Oxford UK: Blackwell Publishing.

Compeau, D. R., \& Higgins, C. A. (1995). Computer self-efficacy: Development of a measure and initial test. MIS Quarterly, 189-211. DOI: $10.2307 / 249688$

Çeliktürk, Z., \& Yamaç, A. (2015). İlkokul ve ortaokul öğrencileri için okuma kaygısı ölçeğinin geliştirilmesi: Geçerlik ve güvenirlik çalışması. İlkögrretim Online, 14(1), 97-107. DOI: 10.17051/io.2015.03320

Çetin, B. (2009). Yeni ilköğretim programı (2005) uygulamalarının ilköğretim 4. ve 5. sınıf öğrencilerinin özyeterliliklerine etkisi. Pamukkale Üniversitesi Eğitim Fakültesi Dergisi, 25(25), 130-141.

Çetin, B. (2013). Çocuklar için öz-yeterlik ölçeğinin ilköğretim 4. ve 5. sınıf öğrencilerinin akademik başarısını yordaması. Kastamonu Ĕ̈itim Dergisi, 21(3), 1117-1132.

Demirel, Ö. (1999). İlköğretim okullarında Türkçe ögrretimi. İstanbul: MEB Yayınları.

Derman A. (2007). Kimya ögretmeni adaylarının öz yeterlik alglları ve öğretmenlik mesleğine yönelik tutumları. (Yayınlanmamış Doktora Tezi). Fen Bilimleri Enstitüsü, Selçuk Üniversitesi, Konya.

Elliott, C. H., \& Smith, L. L. (2010). Overcoming anxiety for dummies. Indianapolis, Indiana: Wiley Publishing.

Eysenck, M. W., Derakshan N., Santos R., \& Calvo, M. G. (2007). Anxiety and cognitive performance: attentional control theory. Emotion, 7(2), 336-353. DOI: 10.1037/1528-3542.7.2.336

Genç, G. (2016). Can ambiguity tolerance, success in reading, and gender predict the foreign language reading anxiety?. Journal of Language and Linguistic Studies, 12(2), 135-151.

Gençtürk, A. (2008). İlköğretim okulu öğretmenlerinin öz-yeterlik alglları ve iş doyumlarının çeşitli değişkenler açısından incelenmesi. Yayımlanmamış Yüksek Lisans Tezi. Zonguldak Karaelmas Üniversitesi Sosyal Bilimler Üniversitesi, Zonguldak.

Göğüş, B. (1978). Orta dereceli okullarımızda Türkçe ve yazın eğitimi. Ankara: Gül Yayınevi.

Grabe, W., \& Stoller, F. L. (2002). Teaching and researching reading. Harlow: Longman.

Guimba, W. D., \& Alico, J. C. (2015). Reading anxiety and comprehension of grade 8 filipino learners. International Journal of Humanities and Social Sciences, 1, 44-59.

Hadidi, E., \& Bargezar, R. (2015). Investigating reading anxiety and performance on reading proficiency: A case of Iranian EFL learners. International Journal of Language and Applied Linguistics, 25, 50-57.

Haris, A. J., \& Sipay, E. R. (1990). How to increase reading ability. New York: Longman.

Hoy, W. K., \& Woolfolk, A. E. (1993). Teachers' sense of efficacy and the organizational health of schools. The elementary school journal, 93(4), 355-372. DOI: http://dx.doi.org/10.1086/461729

İnnali, H. Ö., \& Aydın, İ. S. (2014). İlköğretim 8. sınıf öğrencilerinin okur öz yeterliklerinin çeşitli değişkenlere göre incelenmesi. Turkish Studies-International Periodical For The Languages, Literature and History of Turkish or Turkic, 9(9), 651-682. DOI: 0.7827/TurkishStudies.7132

İşeri, K., \& Ünal, E. (2012). Türkçe öğretmen adaylarının yazma kaygı durumlarının çeşitli değişkenler açısından incelenmesi. Mersin Üniversitesi Eğitim Fakültesi Dergisi, 8(2), 67-76.

Jafarigohar, M., \& Behrooznia, S. (2012). The effect of anxiety on reading comprehension among distance EFL learners. International Education Studies, 5(2), 159-174. DOI: http://dx.doi.org/10.5539/ies.v5n2p159

Jalongo, M. R., \& Hirsh, R. A, (2010). Understanding reading anxiety: new insights from neuroscience. Early Childhood Education, 37, 431-435. DOI: 10.1007/S10643-010-0381-5. DOI 10.1007/s10643-010-03815

Johnson, A. P. (2008). Teaching reading and writing: A guldebook for tutoring and remediating students. Lanham: The Rowman and Littlefield Publishing.

Karsten, R., \& Roth, M. R. (1998). The relationship of computer experience and computer self-efficacy to performance in introductory computer literacy courses. Journal of Research on Technology Education, 31(1), 14-24. DOI: http://dx.doi.org/10.1080/08886504.1998.10782238

Kılınç, H. H., \& Yenen, E. T. (2016). Investigation of students' reading anxiety with regards to some variables. International Journal of Higher Education, 5(1), 111-118. DOI: 10.5430/ijhe.v5n 1p111

Koç, C., \& Arslan, A. (2017). Ortaokul Öğrencilerinin Akademik Öz Yeterlik Algıları ve Okuma Stratejileri Bilişüstü Farkındalıkları. Yüzüncü Yll Üniversitesi Eğitim Fakültesi Dergisi, 14(1), 745-778. DOI: http://dx.doi.org/10.23891/efdyyu.2017.29 
Koizumi, R. (2002). The effect of motivation, language anxiety, and test anxiety on English proficiency of Japanese junior high school students. Japan Language Testing Association Journal, 5, 91-110. DOI: http://doi.org/10.20622/jltaj.5.0_91

Köroğlu, H. (2010). Turkısh elt students' readıng anxiety and their strategles use. (Unpublished Master's Thesis). Kafkas University, The Institute of Social Sciences, Kars.

Kuru Gönen, İ. (2005). The sources of foreign language reading anxlety of students in a Turkish efl context. (Unpublished Master's Thesis). Anadolu Unıversıty, Institute of Educational Sciences, Eskişehir.

Kusdemir, Y., \& Katranci, M. (2016). Anxiety and comprehension in reading: 1 can not find the main 1dea, my teacher! Eğitim ve Bilim-Educatıon and Sclence, 41(183), 251-266. DOI: 10.15390/EB.2016.4951

Linnenbrink A. E., \& Pintrich R.P. (2003). The role of self efficacy beliefs in student engagement and learning in the classroom. Reading \& Writing Quartely, 19, 119-137. DOI: http://doi.org/10.1080/10573560308223

Melanlığlu, D. (2014). Impact of metacognitive strategies instruction on secondary school students' reading anxieties. Egitim ve Bilim, 39(176), 107-119. DOI: 10.15390/EB.2014.3540

Milner, H. R. (2002). A case study of an experienced English teacher's self-efficacy and persistence through" crisis" situations: Theoretical and practical considerations. The High School Journal, 86(1), 28-35. DOI: $10.1353 / \mathrm{hsj} .2002 .0020$

Muris, P. (2001). A brief questionnaire for measuring self-efficacy in youths. Journal of Psychopathology and Behavioral Assessment, 23(3), 145-149. DOI: http://dx.doi.org/10.1023/A:1010961119608

Özata, H. (2007). Öğretmenlerin öz-yeterlik algılarının ve örgütsel yenileşmeye ilişkin görüşlerinin araştırılması. Yayımlanmamış Yüksek Lisans Tezi. Kocaeli Üniversitesi Sosyal Bilimler Enstitüsü, Kocaeli.

Özbay, M. (2009). Okuma ĕgitimi. (1. Bask1). Ankara: Öncü Kitap.

Özdemir, E. (1990). Okuma sanatı. İstanbul: İnkılap Kitabevi.

Özenoğlu Kiremit, H. (2006). Fen bilgisi öğretmenliği ögrencilerinin biyoloji ile ilgili öz-yeterlik inançlarının karşılaştırılması. Yayımlanmamış Doktora Tezi. Dokuz Eylül Üniversitesi Eğitim Bilimleri Enstitüsü, İzmir.

Özgen, K., \& Bindak, R. (2011). Lise öğrencilerinin matematik okuryazarlığına yönelik öz-yeterlik inançlarının belirlenmesi. Kuram ve Uygulamada Ĕ̌itim Bilimleri, 11(2), 1073-1089.

Pajares, F. (1996). Self-efficacy beliefs in achievement settings. Review of Educational Research, 66, 543-578. DOI: https://doi.org/10.3102/00346543066004543

Pajares, F. (1997). Current directions in self-efficacy research. Paul Pintrich \& Martin 1. Maehr, (Eds.), In advances in motivation and achievement. (Vol.10, pp. 1-49). Greenwich: CT: JAI Press.

Pajares, F. (2002). Self-efficacy beliefs in academic contexts: an outline. Erişim tarihi: 02 Ağustos 2017 , http://www.uky.edu/ eushe2/Pajares/efftalk.html.

Pajares, F., \& Schunk, D. H. (2004). Self-efficacy in education revisited. Empirical and applied evidence. V. S. Etten \& D. M. McInerney (Eds.), In big theories revisited (pp. 115-164). Greenwich: İnformation Age Publishing.

Pekrun, R., Goetz, T., \& Perry, R. P. (2005). Academic emotions questionnaire (AEQ)-User's manual. Department of Psychology, University of Munich.

Pekrun, R. (2006). The control-value theory of achievement emotions: Assumptions, corollaries, and implications for educational research and practice. Educational Psychology Review, 18, 315-341. DOI: 10.1007/s10648-006-9029-9

Pekrun, R., Goetz, T., Frenzel, A.C., Barchfeld, P., \& Perry, R.P.(2011). Measuring emotions in students' learning and performance: the achievement emotions questionnaire (AEQ). Contemporary Educational Psychology 36, 36-48. DOI: https://doi.org/10.1016/j.cedpsych.2010.10.002

Rozan, N. (1982). Okuma alışkanlığında öğretmenlerin rolü. Ĕ̆itim ve Bilim, 7(39), 19-23.

Schunk, D. H. (1991). Self-efficacy and academic motivation. Educational Psychologist, 26, 207-231. DOI: http://dx.doi.org/10.1080/00461520.1991.9653133

Schunk, D. H., Hanson, A. R., \& Cox, P. D. (1987). Peer-model attributes and children's achievement behaviors. Journal of Educational Psychology,79(1), 54-61. DOI: http://dx.doi.org/10.1037/00220663.79.1.54

Senemoğlu, N. (2005). Gelişsim, öğrenme ve ögretim: Kuramdan uygulamaya (11. Bask1). Ankara: Gazi Kitabevi.

Sert, A. (2010). İlköğretim altıncı sınıf öğrencilerinin okuduğunu anlama becerilerinin bazı değişkenler acısından incelenmesi. Yayımlanmamış Yüksek Lisans Tezi. Selçuk Üniversitesi EĞitim Bilimleri Enstitüsü, Konya.

Şahin, N. (2011). İlköğretim ikinci kademe öğrencilerinin yabancı dildeki okuma kaygılarının kaynakları ve bu kaygılarla duygusal başa çıkma stratejileri: Bir durum incelemesi. Yayımlanmamış Yüksek Lisans Tezi. Gazi Üniversitesi Eğitim Bilimleri Enstitüsü, Ankara.

Şahin, Y. (2011) Okuma eğitimi. Konya: Eğitim Akademi.

Tazebay, A. (1993). Illkokuma yazma ögretimi. İstanbul: MEB Yayınları. 
Tekindal, S. (2009). Duyuşsal özeliklerin ölçülmesi için araç oluşturma. (Geliştirilmiş 2. Baskı). Ankara: PegemA Yayincilik.

Telef, B. B., \& Ergün, E. (2013). Lise öğrencilerinin öznel iyi oluşlarının yordayıcısı olarak öz-yeterlik. Kuramsal Eğitimbilim Dergisi, 6(3), 423-433. DOI: http://dx.doi.org/10.5578/keg.5955

Telef, B. B., \& Karaca, R. (2011). Ergenlerin öz-yeterliklerinin ve psikolojik semptomlarının incelenmesi / Adolescents' self-efficacy and psychological symptoms' investigation. Mustafa Kemal Üniversitesi Sosyal Bilimler Enstitüsü Dergisi, 8(16), 499-518.

Telef, B. B., \& Karaca, R. (2012). Çocuklar için öz-yeterlik ölçeğinin geçerlik ve güvenirlik çalışması. Buca Eğitim Fakültesi Dergisi, 32, 169-187.

Tobias, S. (1986). Anxiety and cognitive processing of instruction. R. Schwarzer (Eds.). In self-related cognition in anxiety and motivation (pp. 35-54). New Jersey: Hillsdale.

Torgesen, J. K. (2000). Individual responses in response to early interventions in reading: the lingering problem of treatment resisters. Learning Disabilities Research \& Practice, 15, 55-64. DOI: http://dx.org/10.1207/SLDRP1501_6

Tschannen-Moran, M., \& Hoy, A. W. (2001). Teacher efficacy: Capturing an elusive construct. Teaching and Teacher Education, 17(7), 783-805. DOI: https://doi.org/10.1016/S0742-051X(01)00036-1

Turgut, M. F. (1978). Eğitimde ölçme ve değerlendirme. Ankara: Nüve Matbaası.

Üredi, I., \& Üredi, L. (2005). İlköğretim 8. sınıf öğrencilerinin öz-düzenleme stratejileri ve motivasyonel inançlarının matematik başarısını yordama gücü. Mersin Üniversitesi Ĕ̌itim Fakültesi Dergisi, 1(2), 250260.

Williams, A. M., Vickers, J., \& Rodrigues, S. (2002). The effects of anxiety on visual search, movement kinematics and performance in table tennis: A test of Eysenck and Calvo's processing efficiency theory. Journal of Sport and Exercise Psychology, 24, 438-455. DOI: https://doi.org/10.1123/jsep.24.4.438

Woolfolk Hoy, A. (2000). Changes in teacher efficacy during the early years of teaching. American Educational Research Association, 43, 1-20. DOI: 10.1016/j.tate.2005.01.007

Yazıcıoğlu, Y., \& Erdoğan, S. (2004). SPSS uygulamalı bilimsel araştırma yöntemleri. Ankara: Detay Yayıncılık.

Yıldız, M., \& Ceyhan, S. (2016). İlkokul 4. sınıf öğrencilerinin okuma ve yazma kaygılarının çeşitli değişkenler açısından incelenmesi. Turkish Studies International Periodical for the Languages, Literature and History of Turkish or Turkic, 11(2), 1301-1316. DOI: http://dx.doi.org/10.7827/TurkishStudies.9370

Zeidner, M. (1998). Test anxiety: The state of the art. New York: Plenum Press.

Zimmerman, B.J., Bandura, A., \& Martinez-Pons, M. (1992). Self-motivation for academic attainment: The role of self-efficacy beliefs and personal goal-setting. American Educational Research Journal, 23, 614-628. DOI: http://dx.doi.org/10.2307/1163261

\section{EXTENDED SUMMARY}

Introduction: Reading is an important skill both in academic life and in daily life of the individual. When this skill is gained accurately and effectively, the individuals who read fluently and correctly, understand what they read, learn from what they read and convey their thoughts by writing or verbally can be trained. Reading is considered to be particularly important among the four basic language skills, as it is regarded as the major means that help the individual acquire new knowledge and improve himself/herself. The individual is active both cognitively and affectively during the reading process. The reading anxiety felt by the individual during the reading activity occurs in the affective dimension of this process. The state of reading anxiety first appears spiritually, but physical symptoms can also be seen. It requires to take measures to encourage, motivate him/her and reduce the anxiety level in order to prevent the individual from worrying about the reading process. It is stated that using metacognitive strategies is an important factor to reduce the reading anxieties of students. In this case, it can be said that individuals having high self-efficacy can cope with reading anxiety more easily. The concept of selfefficacy is one of the main concepts that is at the core of the Social Learning Theory developed by Bandura for the first time and contains the perception of the individual's self-motivation. Self-efficacy is not a skill but rather a belief that the individual has the answer of the question "What can I do?" using the skills he has in some circumstances. It is also stated that it is easier for the individuals with high self-efficacy belief to cope with the problems.

It is thought that this study should be carried out to determine whether the secondary school students' reading anxiety and self-efficacy beliefs differ in terms of gender, grade level, maternal and paternal education status. It is also aimed to determine the correlation between students' reading anxiety and self-efficacy beliefs. For this purpose, the answers of the following questions will be sought.

a) Are the reading anxiety of secondary school students significantly different according to sex, grade, mother and father education status?

b) Are the self-efficacy beliefs of secondary school students significantly different according to sex, grade, mother and father education status? 
c) Is there a significant relationship between secondary school students' reading anxiety and self-efficacy beliefs?

Method: In the study, non-random sampling method was used. The study was conducted on 496 students, 241 females and 255 males in 11 different secondary schools from Sivas province centre. Two different scales were used in the study to determine the reading anxieties and self-efficacy beliefs of secondary school students. The "Reading Anxiety Scale " developed by Çeliktürk ve Yamaç (2015) were used to determine the student's reading anxiety levels. The reliability of the scale was determined as .92. The "Self-Efficacy Scale for children" adapted by Telef and Karaca (2012) developed by Muris (2001) was used in order to determine the self-efficacy beliefs of the students. The reliability of the scale was determined as .86. In the data analysis, arithmetic average, percentage, T-test, Anova, LSD and correlation analysis techniques were used.

Findings, Discussion and Recommendations: It was determined that the students' reading anxiety differed significantly according to class, father education status variables; the students' academic self-efficacy differed significantly according to class, mother education status and father education status variables. According to the gender variable, it was determined that reading anxiety scores of middle school students did not show any significant difference. According to the grade variable, it was determined that there is a fundamental difference between "the $5^{\text {th }}$ and $7^{\text {th }}$ grades", between "the $5^{\text {th }}$ and $8^{\text {th }}$ grades", "the $6^{\text {th }}$ and $7^{\text {th }}$ grades" and between "the $7^{\text {th }}$ and the $8^{\text {th }}$ grades" in terms of reading anxiety. According to the educational status of the mother, it was determined that reading anxiety scores of middle school students did not show any significant difference. According to the educational status of the father, a significant difference was found out between the "primary school and the university" and significant difference seems to be more in favor of elementary school paternal education. According to the gender variable, it was determined that self-efficacy beliefs scores of middle school students did not show any significant difference. According to the grade variable, it was determined that there is a fundamental difference between "the $5^{\text {th }}$ and $6^{\text {th }}$ grades", between "the $5^{\text {th }}$ and $7^{\text {h }}$ grades", between "the $5^{\text {th }}$ and $8^{\text {h }}$ grades", between "the $6^{\text {th }}$ and $8^{\text {h }}$ grades" and between "the $7^{\text {th }}$ and the $8^{\text {th }}$ grades" in terms of self-efficacy beliefs. According to the educational status of the mother, there is an important difference between "primary school and high school", "secondary school and high school" in terms of self-efficacy beliefs. According to the educational status of the father, there is an important difference between "secondary school and high school", "secondary school and university" in terms of self-efficacy beliefs. According to the correlation results of students' self-efficacy and reading anxiety total scores were found out to be moderate (-.34).

The study can be conducted on different levels of schools. The relationship between reading anxiety and different high-level skills can be studied. The study can be conducted by using qualitative or mixed method to determine the reasons of reading anxiety. Teachers need to plan the activities related to reading skills better and evaluate the data related to the results accurately by using different evaluation techniques. For this purpose, it will be appropriate for teachers to be informed about what kind of tools and equipment will be used for reading. It is thought that it will be useful for students to be assigned at different social events so that they can improve their reading. It is considered that the studies should be conducted appropriately related to the effectiveness of the reading activities at school. 